\title{
Encounters with borders
}

\section{A migrant academic's experiences of the visa regime in the Global North}

\author{
Priya Dixit
}

\begin{abstract}
This article examines (im)obility in the global visa regime through the experiences of a Global South academic working in the Global North. Drawing on an autoethnographic account of a visa application, this article outlines the ways in which the global visa regime negatively affects a Global South academic's life. Visa regulations constitute a particular Global South academic subject in the Global North, one whose academic career is characterised by uncertainty and anxiety, as visas can limit access to promotions and to fieldwork and research opportunities. Visa experiences can thus contribute to alienation and non-belonging of Global South scholars in academia, while impacting knowledge production and teaching.
\end{abstract}

\section{KEYWORDS}

autoethnography, academic mobility, counter-storytelling, Global South, knowledge production, visa

As academia becomes more globalised and there is increasing movement of scholars and students around the world, a number of questions about Global South scholars' participation and engagement in global academia remain unaddressed. A key question is regarding differential access to academic and research opportunities for people from the Global South. These Global South academics, of whom I am one, face multiple barriers that hinder their research collaborations and opportunities to produce and share knowledge, putting them on unequal terms with their Global North counterparts. I use the term 'Global South' here to indicate areas of the world that have been impacted by colonialism and were subject to historical domination and control by colonial powers. As a continuing outcome of colonised modes of global 
mobilities, people from the Global South are considered racially 'other', and their bodies subject to increased surveillance and control especially in the global mobility regime (Spire 2020; Vezzoli and Flahaux 2017). By the 'global mobility regime' here I mean the movement of people - refugees, labourers, students, travellers - across nation-state borders. This article focuses on some of these barriers to equal participation in global academia faced by Global South academics whose bodies are surveilled and categorised as 'other' and as potentially dangerous in the global mobility regime.

In this article, I draw inspiration from Simone Browne's description of 'dark sousveillance' (2015) to illustrate how Global South bodies are subject to surveillance and judgement in the global mobility regime. Through an autoethnographic account showing the denial of the visa application necessary for my proposed research project, I demonstrate how practices seemingly straightforward or easy, such as applying for a short-term visa, are hardly such. Instead, for Global South migrant academics working in the Global North, visa applications are fraught with tension, opaque in their rules, and impose high financial and psychological costs on the applicants. Furthermore, these anxieties about applying for visas are not shared by many colleagues and evaluators in the Global North. This means there is limited attention paid to concerns about the effects of differential mobility for Global North and Global South academics during discussions of job performance of and the retainment and promotion of Global South academics. While existing scholarship on global politics and mobility discusses the practices that make up the global mobility regime to surveil, categorise, and ban certain persons (e.g., Salter 2006, 2011), this article shifts the focus and analyses the moving person and the effects of global visa regimes upon people. I focus on the processes of surveillance and categorisation prior to getting to the airport, processes that centre race and affect Global South academic mobilities.

The article is organised as follows: ${ }^{1}$ The next section briefly discusses race and migration in global academia. The sections after it provide an autoethnographic account of my visa application. This is followed by a discussion about mobility in relation to Global South persons/bodies. The conclusion reflects upon counter-storytelling and its implications for understanding how inequities in academic mobility affect research and knowledge-production and sharing in global academia. 


\section{Race, migration and the global visa regime in academia}

A key site of investigation and analysis of global mobilities, especially the practices of surveillance and control, is the airport. The airport is a place where racialised bodies - Global South bodies - are likely to be viewed as dangerous and are subject to stringent security measures. In recent years, there have been increasing amounts of research about the effects of new global security measures regarding mobility, especially surveillance technologies. Studies have examined effects of surveillance technologies on the identity of the liberal state and on various individuals considered different or 'other' (Finn 2011: 413; Haggerty and Ericson 2006; Kruger et al. 2008). Existing research on mobility at airports has analysed the role played by the assemblage of airport security: shifting borders, biometric requirements, and the transformation of the body itself into a 'passport' that then gets authorised to enter certain spaces (and is excluded from others) (Adey 2008, 2009; Salter 2008). Charlotte Epstein writes,

What is being verified are no longer the documents individuals carry upon themselves, but their bodies. Contrary to what the biometric literature claims, it is not so much about verifying that you are who you say you are, since more often than not you do not actually say anything; but that you are the 'right' body, the one that yields a match . . . For the body is controlled by being known. (2007: 153)

There exists scholarship on transnational migration patterns and the movement of scholars from/of the Global South. There are also discussions about the sociopolitical impacts of such academic migration upon the Global South, as well as impacts upon the migrants themselves as they adjust to unfamiliar academic and societal cultures in the Global North (Cantwell and Lee 2010; Hallett and Eryaman 2014; Maadad 2014; Morley et al. 2019). In a study conducted amongst Non-English-Speaking Background (NESB) international academics in Australia, stresses that affected their experiences were identified (Maadad 2014). Similarly, Sayil Camacho (2017) outlines how race and class intersect in the experiences of international postdoctoral scholars in the University of California university system in the United States. Regula Leemann (2010) examines factors that affect global academic mobility but her focus is on Global North scholars, as is Terri Kim's (2017) and Chris Coey's (2018). David Hoffman (2009) outlines some key themes regarding academic mobility, in general. Heike Jöns (2011) and Leemann (2010) 
examine gendered dimensions of academic mobility, while Başak Bilecen and Christof van Mol (2017) focus on inequalities within academic mobility patterns. However, despite increasing numbers of Global South academics in the Global North, there is limited research on how one becomes an academic migrant or on how visas affect knowledge production and teaching outside of one's home country. That is, there is space for further research about the processes of acquiring a visa that permits and limits mobility and access to research and collaboration opportunities, and the stresses and obstacles associated with such.

For many of us from the Global South, making our bodies knowable to the increasingly anonymous technologies that determine whether we are 'safe' or 'dangerous' starts prior to arriving at an airport: it starts with the process of applying for a visa to travel. In general, a visa is: 'An entry or note on a passport, certificate, or other official document signifying that it has been examined and found correct; a formal official signature or entry of this nature' (Oxford English Dictionary 1989: xix, 681, 686). Visa-free travel is simply the absence of a requirement to hold a visa and is generally considered a privilege (Whyte 2008: 135). While this definition suggests applying for a visa is merely to approve of an applicant's passport, the reality is more complicated. Visa applications have become more complex in recent years, with additional types and requirements added to control and manage global mobilities. A study of visa rules over forty years by Steffen Mau and colleagues (2015) concluded that 'while OECD countries and rich countries have gained mobility rights, mobility rights for other regions have stagnated or even diminished, in particular for citizens from African countries' (2015: 1192). For Global South persons, requirements for a visa - some of which I shall detail below - are often challenging in terms of financial and psychological impacts. Visas can be viewed as a continuation of colonial patterns of management and control, with the colonising power controlling access to its spaces for people from its former colonies (Vezzolli and Flahaux 2017). This ensures the existing hierarchical relationships are maintained and perpetuated.

In addition, colonial relationships wherein archives with historical information about the Global South are maintained in former colonial centres means Global South scholars' ability to access formal archives and to conduct fieldwork in the Global North are also restricted by the global visa regime. Furthermore, Global South academics' ability to build collaborations and research networks in an increasingly global academic market is constrained by forces beyond their control. Despite this, discussions of visa applications 
are not central in discussions of academic mobilities even though visas are essential means of limiting and permitting mobility for Global South persons, including academics. In a globalised world, Global South scholars' ability to acquire a visa shapes their employment opportunities and knowledge production trajectories more so than for their Global North peers. It can also close off Global North areas for fieldwork and archival research. Unlike Global North colleagues who are more mobile, Global South scholars' need for visas means they can be more or less mobile depending on whether they are able to acquire visas or not (Cantwell and Lee 2010). As such, knowledgeproduction and knowledge-sharing from and of the Global South is strongly shaped by the global visa regime. Thus, it is essential to understand how visas structure global mobility patterns and how they affect Global South scholars differently in comparison to Global North scholars.

Methodologically, the majority of research on transnational academic mobility draws upon statistical information (e.g., Whyte 2008) and on life stories and narrative analyses (Hallett and Eryaman 2014; Kum 2018; Leung 2017). This article adopts narrative-based analysis, specifically autoethnography and counter-storytelling inspired by critical race approaches, to illustrate and examine questions of power and inequalities in the visa application process. It is motivated by feminist scholarship on race and surveillance, specifically Simone Browne's theorisation of Black resistance to existing modes of surveillance as 'dark sousveillance'. Browne writes, 'I plot dark sousveillance as an imaginative place from which to mobilise a critique of racialising surveillance, a critique that takes form in antisurveillance, countersurveillance, and other freedom practices. Dark sousveillance, then, plots imaginaries that are oppositional and that are hopeful for another way of being' (2015: 21). Following Browne, this article explores her question of how to make 'imaginaries that are oppositional and hopeful for another way of being' when considering questions of migrant Global South academic labour and their presence in Global North teaching and learning spaces. One way of doing this is through an autoethnographic account of a visa application such that its uncertainties and anxieties can be made transparent. This transparency through a form of autoethnographic counter-storytelling can open up space for discussions of the racialised hierarchies in academic mobility and how that shapes knowledge-production and teaching and learning.

Counter-storytelling here can be understood as stories of experiences of people who have been historically-marginalised, often told by the people themselves. It is both a method and a tool of analysis, as Daniel Solorzano 
and Tara Yosso (drawing on Delgado) explain: '[Delgado (1989)] argues that [counter-storytelling] is both a method of telling the story of those experiences that are not often told (i.e., those on the margins of society) and a tool for analysing and challenging the stories of those in power and whose story is a natural part of the dominant discourse - the majoritarian story' (2001: 475). Counter-storytelling then decentres the traditional stories of academic mobilities as people who face this unequal visa regime write and talk about their experiences and feelings. It acknowledges and makes visible the different experiences of and the challenges to knowledge production for historically marginalised scholars. Instead of yet another data point in increasingly large surveillance databases or disembodied subjects in discussions of surveillance technologies, this emphasis on telling counter-stories is useful to show how some bodies - Black and Brown bodies from the Global South in most cases - are deemed dangerous and threatening in the global mobility regime. Counter-storytelling, thus, centres experiential knowledge of minoritised populations and suggests such knowledge is critical to understanding questions of power and agency in global academia. Relatedly, autoethnography is used as a method to direct attention to the effects of the global mobility regime on (some) Global South persons and to outline power dynamics inherent in the process of 'acquiring a visa' and the attendant surveillance practices. As Marie Breen-Smyth explains, 'autoethnographers, using ethnographic research methods, seek an understanding of the social and political through analysis of the self in interaction with others' (2014: 224).

Overall, through counter-storytelling with the aim of 'sousveillance', this article engages in decentring research on global academic migration. Meghana Nayak and Eric Selbin describe decentring in general as: 'challeng[ing] the politics, concepts and practices that enable certain narratives of International Relations (IR) to be central; decentering is also a way to put forth and participate in other kinds of narratives and politics that have different “starting” points' (2010: 4).

The processes of acquiring a visa and attempting to travel are not commonly documented in the literature on mobility and security, and this is the 'different starting point' for this article. There has also been limited emphasis on the processes of a body getting to an airport and passing through airports (transit). These are, perhaps, partial reflections of who researches and writes about mobility - scholars from and of the Global North who are generally unaffected by transit and other visa restrictions. As Bilecen and van Mol (2017) argue, there are manifold inequalities in the process of academic mobility. 
My illustrative example is the process of applying for a visa as a Global South scholar working in the Global North, and it is to this experience the next few sections turn toward. I use autoethnography as a form of counter-storytelling to describe a journey that did not happen and another that did happen and to draw connections between these journeys and the construction of a mobile (or otherwise) Global South scholar working in the Global North.

\section{Where the borders are}

Let me begin with a story: In order do my planned research on the role of Nepali Gurkha soldiers in the First World War, I had to go to the United Kingdom. This is because principal archives about Gurkha (and many other South Asian) soldiers' historical experiences are located in the UK. I applied for and received funding for this archival research and arranged to go for a period of some weeks on the way back from staying with family in South Asia. At that point, I had been living and working in the United States for over a decade and was in full-time employment at a university in the United States. My plan was first to go home through the UK. On my way back a few weeks later, I would spend a few weeks in the UK again doing archival research and fieldwork (interviewing some retired soldiers) before heading to the United States. But there was a problem - in order to pass through the UK on the way to South Asia, I also needed a transit visa in addition to the visitor/research visa I would need for fieldwork. I then found out I could not apply for both visas at once and that the visitor visa was single entry. The UK Border Authority (UKBA) recommended applying for a visitor visa from the country where the applicant's passport is from. I then decided to apply for a transit visa from the United States (this was for a three-hour stopover in London) and for a short-term research visa from home.

Visa applications are generally expensive and require extensive paperwork but there were five weeks before my trip began. For most of the Global South, short-term visas to Western countries require return tickets, confirmation of lodging, proof of travel insurance, bank statements, pay stubs, and permission from one's employer that the person can leave work for the specified time. In addition, an invitation letter from a conference or a research institution or a local resident is usually asked for. Longer-term visas require the applicant to undergo medical tests as well and to show larger sums of money.

The UKBA web site in the United States said it needed biometric data - a photograph and fingerprints - with the transit visa application (UKBA n/d). ${ }^{2}$ 
At that time, this could only be done at a United States Citizenship and Immigration Services (USCIS) office. The closest USCIS office to where I live is located three hours' car journey away in Charleston, West Virginia. Now, for most people, this would not be much of a problem. For me, it was different. Despite having lived in the United States for a number of years by then, I did not hold a US drivers' license. I did not own a car (and did not plan to). Public transport was not a viable option either. Using public transport, I would have to take multiple buses to Charleston, with the total trip (one-way) taking anywhere between ten and fourteen hours. Both trips would require an overnight stay. ${ }^{3}$ I was teaching four days a week at the time and would have to miss classes to apply for this transit visa.

In the end, I was lucky. One of the PhD students in my department very kindly drove me to Charleston. At the USCIS office itself, the process was surprisingly swift. First, the office had no other applicants there that I could see. A guard asked me my business there and had me sign in. Then, I was asked to go through to a cubicled area where the USCIS officer took my picture and had me scan my fingerprints. I was nervous. What if something went wrong? What if, for some reason, my fingerprints were deemed 'suspicious'? I had had my fingerprints taken before when I applied for a US visa and when I entered the United States but being alone in a large room with the USCIS official while she scanned my fingerprints one by one was somehow more nerve-wracking than being part of a group of people at an embassy or an airport, all of whom were going through the same process. When it came time to be fingerprinted, the initial scans were all unclear. The official kept on telling me to 'loosen your fingers' as they held my hand and wiped off my fingers with a tissue. We redid them a few more times - my fingers would not stop shaking - and, after making sure they 'passed' for the UK visa application, I was told I could leave.

The entire process took less than thirty minutes from the time I entered the USCIS office. We drove over seven hours (to get there and back) for thirty minutes. On the way out of the office, I was told I should fill in an evaluation form. I remember writing that the UK (and other countries who may have similar biometric test requirements for transit visas) should accept fingerprint scans from local police stations and make it easier for those of us - few as we may be - who do not have a USCIS office near us. I did this as a small protest of these many requirements to receive permission just to stay within an airport. I have no idea what happened to any of those suggestions - I have never applied for a UK visa since then. ${ }^{4}$ 
After this, I made sure I had all the other documents including photographs, added the slip that said I had completed my biometric tests, and sent everything to the UKBA in New York. Let me recap what I sent as part of my transit visa application to be allowed to remain at the London airport for three hours: the completed application form with the specified photograph, the application fee of US $\$ 86$, my passport, a copy of my airline ticket, confirmation I had health insurance, three payslips indicating I had a job with regular pay, and a letter from my department chair specifying my salary and that I was expected to return to teach that fall. I also had to include the original document or the notice of action of my US work authorisation document. When I applied for a research visa later, I would have to re-send all this information and re-do the biometric tests. That fee was also higher.

At the time of my application, the UKBA website indicated the average time for decisions for short-term visas - including transit visas - was four days. I had over a month left before my trip. I had been to the UK more than once before and had left it each time without overstaying my visa. I had submitted all my documents as required by the UKBA. From my perspective, I had completed all the requirements for the UK transit visa, submitted my application in plenty of time and believed I just needed to wait for my passport (with visa) to be returned before I could fly. The difficult part of the visa application process was over. I became immersed in the usual end of semester tasks.

\section{Closed borders}

I did not receive acknowledgment that my documents were received by the UKBA in New York but then I did not expect to. I had sent the documents via express mail to New York and knew, via tracking, that the documents were delivered the next day. Almost two weeks after I had sent in my application documents and passport, I received an automated email from the UKBA. The email acknowledged that my documents had been opened. It also said I would get another email when my documents were reviewed by an official and then a final one when the decision on the visa was made. It ended by indicating I could not directly contact the UKBA and repeated that its officials could not comment on individual applications.

This was an unwelcome surprise since I had been thinking I would receive my passport (with the visa) any day. My flight was now only a few weeks 
away. I became anxious. Considering it had taken almost two weeks for the UKBA to acknowledge merely opening my documents, who knew when the review would occur and the decision be made. I could easily miss my flight. I called the airlines and asked them if I could reschedule. I was told this was not possible without a large fee (almost half of what I had paid for the ticket). Also, upon reflection, I realised I did not know when I could reschedule my trip since I had no idea when I might get my passport back. I tried to find other ways to contact the UKBA in New York but my only option for contacting them was through a pre-paid phone call that was expensive and clearly stated would not comment on ongoing visa applications. I had no recourse but to wait.

The days passed. The last few days of the semester were stressful as I awaited news from the UKBA. I finally emailed the UKBA at an address from its Facebook page. I still do not know if anyone ever received this email or read it. In my email, I did not ask the UKBA to make an immediate decision on my application; instead, I said if a decision was not possible in time, then could I have my passport and US work authorisation document returned. During all this, my colleagues, who knew I was having difficulties with the UK visa, kept asking me how the application was going. I had to answer I did not know and had no idea what might happen next. I did not have my passport and other papers back and did not know when I would get them back. I was also worried as the UKBA had my US work authorisation too.

But even at this time, with my departure date only a few days away, there still remained a small part of me that thought I would get the visa. My flight was supposed to leave from Washington, DC, on Sunday, 13 May. That day came and went. On 14 May, I received an email from the UKBA. This is what it said:

\begin{abstract}
Dear Applicant, We regret to inform you that after careful consideration against the immigration rules, your UK visa application has been unsuccessful. Along with the return of your passport and documents, you will find enclosed a detailed notice explaining exactly why your application was refused and information on your appeal rights. (UKBA New York email to author)
\end{abstract}

I received the notice and my passport the next day. Contrary to what the email said, the notice letter did not explain why my application was rejected. The letter said: 
You have applied for a visa to pass through the United Kingdom en route to Nepal. I have carefully considered your application but I am not satisfied you qualify for such a visa. I therefore refuse your application. There is no statutory right of appeal against this decision. (UKBA New York letter to author)

It was not signed by any individual person. As my visa had been rejected, I could not transit through the UK. I was upset but did not have anyone to talk with. 'You can always apply again', colleagues said. But each visa rejection has to be declared when applying for any other visas. I was scared this rejection would affect my US work visa renewal. I did not want to apply again for another UK visa - what if it was rejected again? This rejection also disrupted my plan for doing fieldwork and archival research in the UK. Indeed, my entire research project was now wrecked as I could not access official archives or talk with retired and current soldiers in the UK. What would I do about my long-term research goals upon which my career depended? I was not sure what I could do - everything seemed overwhelming and obstacles to accessing information seemed unsurmountable. After all, there was no guarantee the UK would grant me a visitor/research visa if they denied me a transit visa that was to allow me to remain in the airport for three hours. I dared not try again. On a practical level, if I still wanted to go to South Asia, I would have to buy a new ticket. Tickets from the United States, especially in early summer and bought with a week's notice, do not come cheap but I wanted to go home now more than ever.

\section{Crossing (some) borders}

The most affordable ticket was with Qatar Airways and included a fifteenhour stopover in Doha. While I would have to spend those fifteen hours inside the Doha airport, there was no need for a transit visa. When I actually got to fly, the journey was uneventful. Doha airport has wireless and seats to nap on while waiting for the next flight and that is what I did. A day or so after I had left the United States, I was in South Asia.

The return trip to the United States was also without incident as these things go - extra security checks at Doha airport for passengers flying to the United States and lining up with other passengers to provide my fingerprints and photograph when we landed in Washington, DC - all 'normal' procedures for today's traveller entering the United States. 


\section{(Un)moving bodies in the global visa regime}

This requirement of a visa for the people who desire to travel through and within its spaces is a form of state control. By controlling access and prohibiting (some) people from entering, techniques such as that of the visa regulate global movement while ensuring the various spaces remain undisturbed by those deemed unfit to be present therein. This affects scholars and students from the Global South who are researching and living in the Global North. Furthermore, the operations of the visa system reinforce existing hierarchies between the 'safe' spaces of the Global North (which include many former colonising powers) and the 'unsafe' spaces of the Global South (which includes many former colonised places). Additionally, Global South students and scholars are often placed in difficult situations as their identities as international students and scholars clash with the increasingly restrictive immigration policies of their host countries. Karen Valentin (2012)'s ethnographic account of Nepali students in Denmark illustrates this tension as an increasingly international education market seeks to attract students while the same students are viewed as immigration problems if they are from the Global South. As Eric Neumayer (2006) states, there is acceptance of and ease of mobilities for passport holders from privileged countries, while there are increasing restrictions for others. The logic behind and the reasons for a visa are to ensure the physical boundaries of the state are in place and remain shored up against seemingly threatening bodies.

But, why is any of this worth describing? After all, I was one of thousands of people from the Global South who attempted to enter or pass though the Global North every day. Unlike many others, I have a series of privileges - I was not in physical danger that required me to leave the Global South. I had a job so when my original UK visa was denied, I could buy another ticket and fly to South Asia by another route. After all, as the UKBA document stated, the UK was under no obligation to approve all visa applications. If its border agents decided they did not want to issue me a visa, I was not the first and nor am I the last to whom this will happen. So, why write about this experience with the global visa regime?

To answer that, let me return to the topic of this article - academic migration from the Global South. The criteria for what counts as 'good research' is connected to globalising scholarship. Existing research indicates internationalisation has positive effects on collaborative knowledge production (Coey 2018). Academics are expected to share knowledge, have national and inter- 
national networks, and, as noted in my example above, conduct research that often requires international fieldwork. These norms of academia determine promotions, continued appointments, and publications. Indeed, as Marton Demeter (2019) shows by interviewing 426 communications scholars from the Global South, 'we found it is almost impossible to become an internationally recognised scientist in communication research without Global North capital' (Demeter 2019: 578). Global South scholars in other disciplines face similar issues. Due to the global visa regime, all these norms are affected and prove to be obstacles that Global South academic migrants face, obstacles that are usually not present for Global North academics. For example, let me provide a hypothetical example of an individual who holds a US passport and wants to travel to the UK. By virtue of their passport alone, this individual is allowed to cross borders and enter UK space without a prior visa. There are no disruptions of work or life as the person does not need to travel to apply for a visa. Travelling becomes a matter of finances and time. The anxieties and uncertainties associated with Global South scholars' travelling and acquiring a visa are not experienced by the millions of travellers from the Global North who will never have to go through such processes.

These are not privileges that Global South bodies have. This lack of consistency in the way the global visa regime is applied indicates the different experiences of 'normal' movement and 'normal'/safe body that occur. It indicates the constant state of uncertainty that Global South students and scholars live with in regard to 'global academic mobility' and their relationship with the 'global'. The decision - being denied a visa - is arbitrary and it is often difficult to receive feedback on rejections or to appeal them. Feelings thus produced - an anxious wait for the decision, even after you know you have already provided all the required paperwork - go beyond abstract descriptions of processes of acquiring a visa and beyond descriptions of modes of surveillance. For long-term academic migrants, Nina Maadad (2014) discusses how just the process of moving to a new culture is confusing and stressful. The process of applying and waiting for a visa adds an additional layer of anxiety to this process.

Borders are not just at airports or when physically entering a state but can be anywhere. In my experience, the UK border manifested itself in a small USCIS office in Charleston, West Virginia, and in a (larger, I presume) office in New York. For US and other Global North passport-holders, the norm would be that the border would not have manifested itself until the Global North body passed through physical immigration controls, usually at a UK 
airport. There would have been no need to produce documents, pay fees, file forms and stress prior to flying; one could buy an air ticket and fly the same day if the US body so desired. In general, the 'confessionary' aspect wherein all plans to travel overseas have to be approved by an authority figure even before the visa application is submitted does not apply to United States (and other Global North) bodies. These Global North bodies can, often, acquire a visa online or at the airport/point of entry.

The question of standpoint is worth elaborating upon here - from the standpoint from which I am writing this, from within academia in the Global North, this tale of my journey(s) is something that is outside of the normal experience for many of my friends and colleagues in the United States - 'do you have your travels worked out?', I was asked more than once during those weeks. No, I did not. Later, when I told them my application was rejected, they were sorry. 'I can't believe they [the UK Border Agency] did this', I was repeatedly told. 'Can't you complain?' But complain to whom? Complain about what? After all, the UK does not have to approve all visa applications. For many people from the Global South, having a visa rejected even if you provided all the documentation is not unexpected; indeed, it is normal. As is the anxiety that accompanies a visa application.

\section{Telling counter-stories of global mobility: Making Global South bodies visible}

Experiences of the global visa regime remain under-narrated and understudied in discussions of mobility, including academic mobility (Mihut et al. 2017). Visas structure the conditions of livelihood of Global South academics in the Global North by increasing anxiety, adding to uncertainty about fieldwork and research possibilities, preventing knowledge-sharing, and restricting access to fieldwork and archives. Narrating experiences of visas and subsequent encounters with borders, as I have attempted to do here, can illustrate these different experiences of Global South academics in Global North academic settings, generating awareness and hopefully building solidarity.

Such storytelling can also subvert processes that categorise some bodies as dangerous or not, while also illustrating how pseudo-objective many of these surveillance and categorisation techniques are. Techniques of seeing and surveillance in the global mobilities regime depend on abstraction and classification of bodies into 'safe' bodies that would then be granted permis- 
sion to move and 'unsafe' bodies that would be denied entry into particular spaces. Scholars of mobility have suggested bodies become invisible and reproduced continuously as data - 'bodies, and knowledge of bodies, are abstracted into data which may be sifted, tabulated, and searched' (Adey 2009: 277). But it is not just abstract visa rules that categorise Global South bodies; it is also actions of individuals located in places out of reach of visa applicants and who are unable to be interrogated about their decisions. These individuals have the power to recognise and authorise entry or deny recognition.

In broad terms, applying for a visa is asking for recognition from a system and a series of practices wherein Black and Brown bodies have historically been produced as dangerous and as threatening. The system itself is inconsistent and, often, opaque. It constructs and maintains racialised hierarchies, as is the case with the global visa regime (Neumayer 2006). This is similar to Ruha Benjamin's discussion with regard to the inequalities that emerge from new technologies in Race after Technology (2019). In my example here, a visa application in the United States meant the UKBA official gazed at my documents and photographs - my body was (presumably) viewed. However, I was not allowed to gaze or speak back in return. The seeing was unidirectional, and I became produced as a dangerous body that would be barred from UK airport space based on my application documents. Telling this story here is a form of counter-storytelling that builds moments of resistance by making the arbitrary visa processes more transparent.

From the standpoint of Global South academics, we can redefine risk not as the individual mobile body; instead, the processes that categorise and authorise persons to move into and across particular spaces are themselves risky when experienced by the Global South person. This surveillance and categorisation of 'otherness' as risky is a key feature of the new technologically-sophisticated surveillance state that has emerged since 11 September 2001. But, of course, for some communities, these techniques of surveillance are not new (Browne 2015). Technology has merely intensified the techniques of policing and governing. The surveillant gaze also operates unevenly in the sense that just being 'not dangerous', even when individual data is checked against Homeland Security/US databases, for example, is inadequate for authorising mobility. Even when the person's body is seen, categorised and checked against biometric databases to ensure it is 'safe' and 'known', mobility is not guaranteed. It is impossible to know who is considered 'safe' in these circumstances. 
We can note from this experience that being visible in the global visa regime entails two contradictory meanings for persons of the Global South: on the one hand, it is desirable for the body to become visible and known so that they can speak and be heard. On the other hand, being known, by being flagged during the visa process, is not desirable as this would lead to being classified as 'suspect' or 'dangerous'. Epstein makes this point: 'Ironically enough, in a system that tends towards total visibility, the normal traveller has become the invisible, unremarkable. The exception is the visible, or at least it is what the system seeks to render visible, by, literally, putting a face (or a fingerprint) to a name' (2007: 154). In my experience, one assumes it was not my physical characteristics (biometrically 'proved' to be 'safe') nor my behaviour (after all, I never saw or spoke to a UKBA official) that was suspect and thus the reason for the rejection of my application. But what was? I do not know and it is this uncertainty and anxiety that becomes central to the visa application process for many Global South academics.

\section{Conclusion: Future (im)mobilities}

The story I tell here is of one visa rejection and the subsequent end of a planned research project. At a time when children are incarcerated in cages, when asylum seekers are detained, and when family and friends from many parts of the world are disallowed entry into the United States, this issue of Global South academics' mobilities seems somewhat trivial. But these are part of broader patterns of state control and an illustration of unequal mobility potentials of Global North and South persons. Migration and borders are racialised, as bodies from the Global South are surveilled, categorised and, often, barred from entering Global North spaces.

For Global South academic migrants, the role played by visas in overseas scholars' lives are barely mentioned in discussions of promotions and employment continuation. Because of its unequal impact on Global South and Global North individuals, the global visa regime becomes something that is unspeakable - the experiences of the Global South academic are unlikely to be shared by Global North colleagues and associates.

Thus, this article is one attempt to respond to these silences, where 'to respond' is writing, speaking, articulating about the contingent and uncertain processes of the global visa regime for Global South academics. Those who do not experience this contingency - such as persons of the Global North have to be made aware of the disruptions and uncertainties that are everyday 
experiences for those who are from the Global South. Indeed, exceptional practices of resistance called for by mobilities scholars - that of reviving contingency and uncertainty (see, e.g., Amoore 2009) - are the norm for many Global South persons in the global mobility regime.

Therefore, for many of us of the Global South, resistance to the global mobility regime is not about recovering contingency or being aware of the contingent nature of global mobilities since such an awareness is continuously present as we try to negotiate our way across borders. Contingency and anxiety are our everyday, not the exception.

Defining resistance as calling for contingency and an awareness of contingency is mainly for those who do not experience it daily. Such calls for contingency indicate, partly, the gap between those who face uncertainty and contingency as the norm and those who need reminding that it is a feature of travel and of life for many. For those of us for whom global uncertainty is the norm, contingency is not resistance. Instead, resistance, then, is speaking of this experience, writing about it, trying to make sense of it by outlining contradictions and variability in the global visa regime - outlining its cracks, as it were. Resistance then is about acknowledging these different experiences in the global mobility regime and how we - Global South persons - are subject to evaluation as potentially dangerous bodies that must be surveilled and contained. For example, my body was deemed 'safe' to pass through and to reside in Qatari and US spaces; and yet it was 'not safe' to pass through UK space for a much shorter period of time. What were the logics of this? What made this same body 'safe' for Qatar and the United States but not for the UK? Articulating one's experiences even within the framework of others' language and practices can be a form of resistance as it makes the body visible, makes it speak and makes the absurdities of surveillance and control (via visas, in this case) evident.

\section{Acknowledgments}

I am extremely grateful to the editors and reviewers of this journal for their thoughtful comments and reviews that assisted in developing and strengthening this article. Any deficiencies in language and otherwise are my own. I also thank the PhD student who kindly drove three hours each way so I could complete the biometrics requirement for my (rejected) UK transit visa application. 
Priya Dixit's research interests are international relations and qualitative research methodologies, especially discourse analysis and ethnography from a postcolonial perspective. Priya has published about qualitative research methods to study security and terrorism, and on visual methods. She compared narratives of counterterrorism in Nepal and the United Kingdom in The State and Terrorism: The Social Construction of State Terrorism (Manchester University Press, 2015). Her current research analyses narratives of far-right extremist actors in the United States. As an academic from Nepal working in the United States, she is interested in pedagogical issues encountered by Global South scholars.

\section{Notes}

1. I am grateful to a reviewer for their comments, which were extremely helpful in organising this article.

2. 'The biometric data of those applying for a UK visa in the United States will be checked against the US Department of Homeland Security's watch list of criminals and immigration offenders.' UKBA (United Kingdom Border Agency) (n.d.) 'Visas', http://ukinusa.fco.gov.uk/ en/visiting-uk/visas/ (accessed 2 May 2021).

3. Of course, this reflects how the US public transport system generates differential mobility (lower-income people are unable to move around easily) and creates and maintains a dependence on oil and automobiles. Nationwide bus and train tickets (Greyhound and Amtrak) are not cheap either.

4. A visitor visa application for the 2015 European International Studies Association Conference in Italy required an in-person interview at the Italian consulate in Philadelphia. Completing the interview took three days, including travel time to go to Philadelphia from where I live and work. This visa application (fee and travel for the interview) cost more than my airfare from Washington, DC, to Italy.

\section{References}

Adey, P. (2008), 'Airports, mobility and the calculative architecture of affective control', Geoforum 39, no. 1: 438-451. https://doi:10.1016/j.geoforum.2007.09.001.

Adey, P. (2009), 'Facing airport security: Affect, biopolitics, and the preemptive securitisation of the mobile body', Environment and Planning D-Society and Space 27, no. 2: 274-295. https://doi.org/10.1068/d0208. 
Amoore, L. (2009), 'Lines of sight: On the visualization of unknown futures', Citizenship Studies 13, no. 1: 17-30. https://doi.org/10.1080/13621020802586628.

Benjamin, R. (2019), Race after Technology: Abolitionist Tools for the New Jim Code (New York: Polity Press).

Bilecen, B. and C. van Mol (2017), 'Introduction: International academic mobility and inequalities', Journal of Ethnic and Migration Studies 43, no. 8: 1241-1255. https:// doi.org/10.1080/1369183X.2017.1300225.

Breen-Smyth, M. (2014), 'Theorising the "suspect community”: counterterrorism, security practices and the public imagination', Critical Studies on Terrorism 7, no. 2: 223-240. https://doi.org/10.1080/17539153.2013.867714.

Browne, S. (2015), Dark Matters: On the Surveillance of Blackness (Durham, NC: Duke University Press).

Camacho, S. (2017), 'Postdoctoral scholars at the University of California: Constructing a migrant identity within the workplace', PhD diss., UCLA.

Cantwell, B. and J. Lee. (2010), 'Unseen workers in the academic factory: Perceptions of neoracism among international postdocs in the United States and the United Kingdom', Harvard Educational Review 80, no. 4: 490-517. https://doi.org/10.17763/ haer.80.4.w54750105q78p451.

Coey, C. (2018), 'International researcher mobility and knowledge transfer in the social sciences and humanities', Globalisation, Societies and Education 16, no.2: 208-223. https://doi.org/10.1080/14767724.2017.1401918.

Demeter, M. (2019), 'So far, yet so close: International career paths of communication scholars from the global south', International Journal of Communication 13: 578602, https://ijoc.org/index.php/ijoc/article/view/10181.

Epstein, C. (2007), 'Guilty bodies, productive bodies, destructive bodies: Crossing the biometric borders', International Political Sociology 1, no.2: 149-164. https://doi.org/ 10.1111/j.1749-5687.2007.00010.x.

Finn, R. (2011), 'Surveillant staring: Race and the everyday surveillance of South Asian women after 9/11', Surveillance \& Society 8, no. 4: 413-426. https://doi.org/ 10.24908/ss.v8i4.4179.

Haggerty, K. and R. Ericson (eds) (2006), The New Politics of Surveillance and Visibility (Toronto: University of Toronto Press).

Hallett, F. and M. Y. Eryaman (2014), 'Beyond diaspora: The lived experiences of academic mobility for educational researchers in the European higher education area', in N. Maadad and M. Tight (eds), Academic Mobility: International Perspectives on Higher Education Research 11. (Bingley, UK: Emerald Group Publishing Limited), 61-78.

Hoffman, D. M. (2009), 'Changing academic mobility patterns and international migration: What will academic mobility mean in the 21st century?' Journal of Studies in International Education 13, no. 3: 347-364. https://doi.org/10.1177/1028315308321374. 
Jöns, H. (2011), 'Transnational academic mobility and gender', Globalisation, Societies and Education 9, no. 2: 183-209. https://doi.org/10.1080/14767724.2011.577199.

Kim, T. (2017), 'Academic mobility, transnational identity capital, and stratification under conditions of academic capitalism', Higher Education 73, no. 6: 981-997. https:// doi.org/10.1007/s10734-017-0118-0.

Kum, H. A. (2018), 'Complexities and cross-cultural challenges of foreign lecturers: Personal narrative histories in Cameroon and England', in A. Hosein, N. Rao, C. Shu-Hua Yeh, and I. M. Kinchin (eds), Academics' International Teaching Journeys: Personal Narratives of Transitions in Higher Education (New York: Bloomsbury Academic), 25-44.

Kruger, E., S. Magnet and J. van Loon (2008), 'Biometric revisions of the "body" in airports and US welfare reform', Body \& Society 14, no. 2: 99-121. https://doi.org/ $10.1177 / 1357034 X 08090700$.

Leemann, R. J. (2010), 'Gender inequalities in transnational academic mobility and the ideal type of academic entrepreneur', Discourse: Studies in the Cultural Politics of Education 31, no. 5: 605-625. https://doi.org/10.1080/01596306.2010.516942.

Leung, M. W. H. (2017), 'Social mobility via academic mobility: Reconfigurations in class and gender identities among Asian scholars in the global north', Journal of Ethnic and Migration Studies 43, no. 16: 2704-2719. https://doi.org/10.1080/ 1369183X.2017.1314595.

Maadad, N. (2014), 'Global academics moving down under: Living and learning a new academic culture', in N. Maadad and M. Tight (eds), Academic Mobility (Bingley, UK: Emerald Group Publishing Limited), 137-151.

Mau, S, F. Gülzau, L. Laube and N. Zaun (2015), 'The global mobility divide: How visa policies have evolved over time', Journal of Ethnic and Migration Studies, 41, no. 8: 1192-1213. https://doi.org/10.1080/1369183X.2015.1005007.

Mihut, G., A. de Gayardon and Y. Rudt (2017), 'The long-term mobility of international faculty', in M. Yudkevich, P. G. Altbach, and L. E. Rumbley (eds), International Faculty in Higher Education: Comparative Perspectives on Recruitment, Integration, and Impact (New York: Routledge), 15-31.

Morley, L., D. Leyton and Y. Hada (2019), 'The affective economy of internationalisation: migrant academics in and out of Japanese higher education', Policy Reviews in Higher Education 3, no.1: 51-74. https://doi.org/10.1080/23322969.2018.1564353.

Nayak, M. and E. Selbin (2010), Decentering International Relations (London: Zed Books).

Neumayer, E. (2006), 'Unequal access to foreign spaces: How states use visa restrictions to regulate mobility in a globalized world,' Transactions of the Institute of British Geographers 31, vol. 1: 72-84. https://doi.org/10.1111/j.1475-5661.2006.00194.x.

Salter, M. (2006), 'The global visa regime and the political technologies of the international self', Alternatives: Global, Local, Political 31, no. 2: 167-189. https://doi.org/ 10.1177/030437540603100203. 
Salter, M. (2011), 'International cooperation on travel document security in the developed world', in R. Koslowski (ed.), Global Mobility Regimes (New York: Palgrave MacMillan), 115-129.

Salter, M. (ed.) (2008), Politics at the Airport (Minneapolis: University of Minnesota Press).

Solorzano, D. G. and T. J. Yosso. (2001), 'Critical race and LatCrit theory and method: Counter-storytelling', International Journal of Qualitative Studies in Education 14, no. 4: 471-495. https://doi.org/10.1080/09518390110063365.

Spire, A. (2020), 'The weight of France's colonial past on immigration policy', in G. Laschi, V. Deplano and A. Pes (eds), Europe between Migrations, Decolonization and Integration (1945-1992) (New York: Routledge), Chapter 12.

UKBA (United Kingdom Border Agency) (n.d.), 'Visas', http://ukinusa.fco.gov.uk/en/ visiting-uk/visas/ (accessed 2 May 2021).

Valentin, K. (2012), 'Caught between internationalisation and immigration: The case of Nepalese students in Denmark', Learning and Teaching: The International Journal of Higher Education in the Social Sciences 5, no. 3: 56-74. https://doi.org/10.3167/ latiss.2012.050304.

Vezzoli, S. and M-L. Flahaux (2017), 'How do post-colonial ties and migration regimes shape travel visa requirements? The case of Caribbean nationals', Journal of Ethnic and Migration Studies 43, no. 7: 1141-1163. https://doi.org/10.1080/ 1369183X.2016.1228446.

Whyte, B. (2008), 'Visa-free travel privileges: An exploratory geographical analysis', Tourism Geographies 10, no. 2: 127-149. https://doi.org/10.1080/14616680801999984. 